\title{
Aircraft Maintenance Technical Education: A Research on Professional Exams
}

\author{
Savaş S. Ateş ${ }^{1}$, Haşim Kafalı², Hasan Lik ${ }^{1}$ \\ ${ }^{1}$ Faculty of Aeronautics and Astronautics, Department of Aviation Management, Eskişehir Technical University, \\ Eskişehir, Turkey \\ ${ }^{2}$ Dalaman School of Civil Aviation, Department of Aviation Management, Muğla Sttkı Koçman University, Turkey \\ "hasimkafali@mu.edu.tr
}

Received: 20 September 2018

Accepted: 08 November 2018

DOI: $10.18466 /$ cbayarfbe. 461965

\begin{abstract}
Aircraft maintenance technician is a profession that needs to be licensed according to international aviation organizations. Aircraft Maintenance Training standards are awarded according to the standards set by EASA Part 66/147 as determined by the European Aviation Agency (EASA). It has been published in SHY66/ 147 by the Directorate General of Civil Aviation (DGCA) in Turkey, which contains documents similar to EASA. Aircraft Maintenance Technician examinations (SHY66 Module Exams) can be carried out by SHY147 Basic Training Institutions which is authorized by the DGCA. DGCA has granted Anadolu University as the authority to make exams in Turkey. The study was carried out in order to determine the exam system perceptions of candidates who entered the SHY66 Module Examinations, which provides Air Vehicle Maintenance Training in Turkey. In the first part of the study, with international and national standards for aircraft technician training was provided with literature. In the second part, survey dimensions developed to measure the test system perception are explained. In the third part, the questionnaire designed to determine the perceptions of the candidates of the aircraft maintenance technicians who entered SHY66 Module Examination was analyzed. The survey was completed by 506 technician candidates. With the results of the analysis, suggestions have been made to develop examinations for SHY66 Module Examinations.
\end{abstract}

Keywords: Aircraft Maintenance, Aviation Training, Aircraft Technician, SHY66, SHY147.

\section{Introduction}

Aircraft maintenance technician is a profession that needs to be licensed according to international aviation organizations. Licensing of technicians in Turkey started with the instruction of SHDT-35 on 31 December 1962. In these years, the licensing standards were based on the International Civil Aviation Organization (ICAO) "Annex 1 Personnel Licensing" manual published in 1948 [1, 2]. Aircraft technician licensing procedures in Turkey were determined by the Joint Aviation Regulations (JAR) standards within the framework of European Union laws in 1996 [3]. After 2005, the authority to determine aviation rules was transferred to EASA, which was established by the European Union [4, 5]. In the transition from JAR to EASA, Turkey lost its membership status. In the case of a future EU membership in Turkey, almost all regulations and instructions are issued in accordance with EASA so that existing licenses can be recognized by EASA [6].

Aircraft Maintenance Training standards are awarded according to the standards set by EASA Part 66/ 147 as determined by the European Aviation Agency (EASA). It has been published in SHY66/ 147 by the Directorate General of Civil Aviation (DGCA) in Turkey. The institutions providing training in accordance with these standards are authorized by the Civil Aviation Authority DGCA. The authorized education institutions are standardized about the length of time, content, and the level of the courses, the number of the questions exams and absenteeism. In this framework, the requirements for a student how to get an air aircraft maintenance license are received determined $[7,8]$.

Maintenance of air vehicles is one of the most important parts of flight operation [9]. Maintenance of aircrafts (SHY145 /EASA Part 145) is maintained at the authorized maintenance centers by Authorized maintenance personnel according to SHY66 /EASA Part66 [2]. The SHY66 /EASA Part66 license gives the authority to maintain and approve the aircrafts. The EASA regulates the training institutions and the exams they make in order to receive this approval. Thus, both the person who wants to be a maintenance technician and the technician educational institutions must be under the EASA conditions. The authorities can be summarized as follows $[2,10]$ :

- Educational institutions are authorized according to SHY147 /EASA Part147,

- Examination institutions are authorized according to SHY66 /EASA Part66, 
- Aircraft maintenance centers are authorized according to SHY145 /EASA Part 145.

Candidates for B1 or B2 category who are trained by authorized educational institutions that are in compliance with EASA standards are required to have 2 years of experience. This period is 3 years for candidates who are not trained but graduated from any vocational training institution. Candidates who do not receive any vocational training are required to have 5 years of experience [2].

The national authority may require additional qualifications from the candidates seeking aircraft maintenance licenses, provided that they are not below the minimum qualifications specified by the EASA [11]. In this sense, the Turkish civil aviation authority requires the minimum English language proficiency required as an extra vocation [12].

The general requirements for obtaining a SHY66 /EASA Part 66 license are as follows [13,14]:

- Person applying for an aircraft maintenance license must be 18 years old,

- Person have to understand of the technical documents issued in the relevant aircraft type, and to read, write and speak at the level that the approved maintenance organization can understand the languages or languages in which the procedures for issuing the maintenance exit certificate are written on SHY-145/ Part-145 or SHY-M/ Part-M,

- Completion of the examinations of the modules related to their request,

- It is necessary to complete the active aircraft maintenance experience in the category related to the claim.

Educational institutions in Turkey are divided into 3 categories by SHGM. These;

- Authorized training institutions,

- Recognized educational institutions,

- Unauthorized educational institutions.

In addition to these applications, the Turkish Civil Aviation Authority SHGM has granted a school status to the aviation vocational high school. If they graduate with a score of over 75 out of 100 , they will not be required to take the SHY66 module exam. These candidates can get an aircraft maintenance license after 3 years of experience [15].

The education institutions with an authorized school status, after 2400 hours of training, all relevant modules are required to be tested and they are eligible for an aircraft maintenance license after 2 years of sector experience.

EASA and SHGM have no obligation to obtain an aircraft maintenance license, although they have been required to take training to enter the module exams necessary for pilot licenses candidates. Training provides a reduction in the duration of experience.

SHY66 /EASA Part 66 airline maintenance license categories [16,17]:

- Category A: Line maintenance mechanical technician,

- Category B1: Aircraft maintenance technician (Mechanical),

- Category B2: Aircraft maintenance technician (Avionic),

- Category C: Aircraft maintenance engineer /technician

The A and B1 categories are divided into subcategories related to the combination of aircraft, helicopters, turbine and piston engines. These subcategories $[16,17]$ :

- A1 and B1.1: Turbine Airplanes,

- A2 and B1.2: Piston Airplanes,

- A3 and B1.3: Turbine Helicopters,

- A4 and B1.4: Piston Helicopters.

B3 category can be applied to non-pressurized aircraft with piston motors below $2000 \mathrm{~kg}$ MTOM (Maximum Take Off Mass).

\section{Materials and Methods}

The study was carried out in order to determine the exam system perceptions of candidates who entered the SHY66 Module Examinations, which provides Aircraft Maintenance Training in Turkey. The questionnaire was asked via the web page used to access the SHY66 module exams. The survey was conducted with a total of 506 technician candidates. It was used in the questionnaire design Önal and Akalın after the scales were fieldspecific revised [18, 19]. Efforts are being made to develop valid, reliable measurement tools and to minimize the problems in the measurements of aircraft maintenance technical professional exams. One of the most important problems with the tests is the bias of the test items. Measurement specialists and researchers are debating whether psychological measures can be misleading [20]. Likelihood is the presence of certain qualities of substances that can make a difference in the performances of the same ability level but which are measured by individuals of different ethnic origins, sexes, cultures and denominations. Likelihood can also be defined as an invalidity or systematic error in the measurement of a substance belonging to a particular group of test substances.

\section{Results and Discussions Demographic Structure of Attendants}

Figure 1 shows the distribution of the genders of candidates who want to obtain an airline maintenance license. The context of aviation maintenance sector is evaluated as heavy and dangerous work by ladies. The aviation maintenance sector is not very favored by female for reasons such as shift work, working difficulties on the 
aircraft and the aircraft, and difficulties in working in cold and hot conditions. Because of that reasons aviation sector is a low-preference by women. As a result, the number of female candidates entering the exams to obtain an aircraft maintenance license is low.

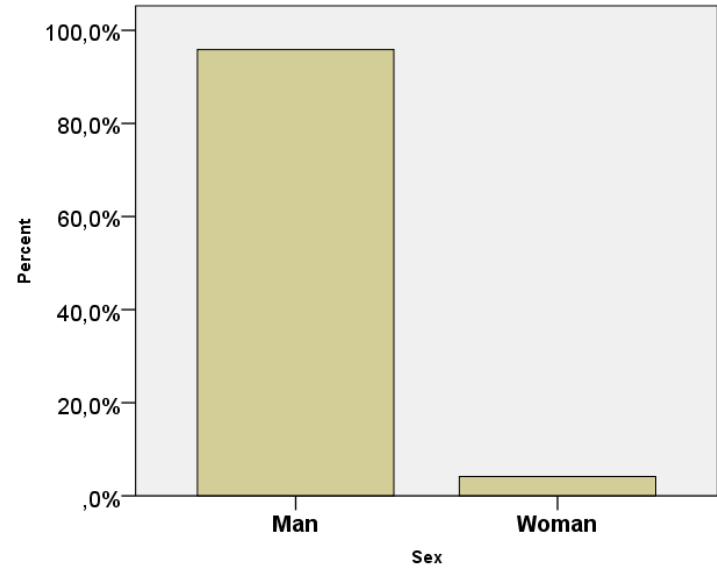

Figure 1. Sex.

Figure 2 shows distribution preferences of candidates who want to obtain aircraft maintenance license according to their license categories. Approximately 70\% of authorized maintenance technicians working in a maintenance organization by EASA standards are in category A, $20 \%$ in B 1 category, $7 \%$ in B2 category and $3 \%$ in $\mathrm{C}$ category. In other words, less than $10 \%$ of the mechanical strength of $90 \%$ is avionics. Approximately $68 \%$ of the candidates entering the SHY 66 module exams appear to be mechanistic, and $32 \%$ of the candidates to apply in the avionics category.

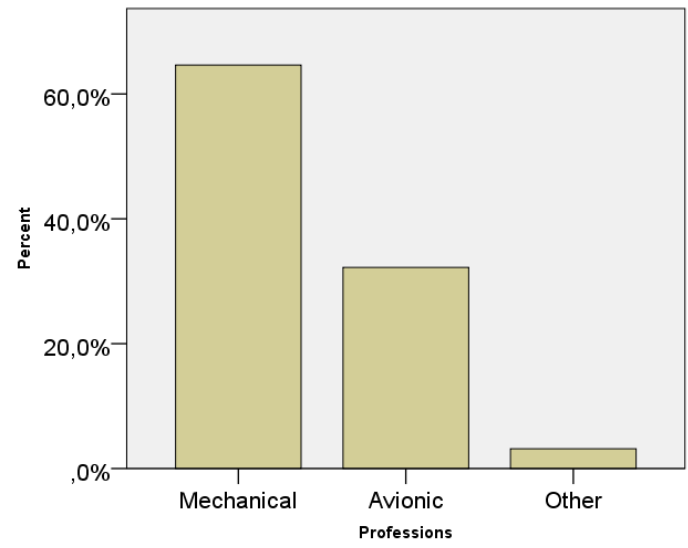

Figure 2. Professions

Figure 3 shows distribution preferences of candidates who want to obtain aircraft maintenance license according to their license categories. Approximately $70 \%$ of authorized maintenance technicians working in a maintenance organization by EASA standards are in category A, $20 \%$ in B1 category, $7 \%$ in B2 category and $3 \%$ in $\mathrm{C}$ category. In total, $70 \%$ of those who enter the class should be in category $\mathrm{A}$, whereas it is seen that 1$2 \%$ of those who entered class is in class. B1 and B2 category air vehicle maintenance license should be around $25 \%$ of the number of authorized personnel. It is seen that nearly $90 \%$ of the candidates who entered the exams entered exams in the B1 and B2 categories. Candidates tend to be regulated in part because of their tendency to categorize, especially to A category. There is no training requirement to enter the $\mathrm{B}$ category exams. All requests can apply. Candidates must have a system of examinations and assessments that is the main determinant for the $\mathrm{B}$ category license.

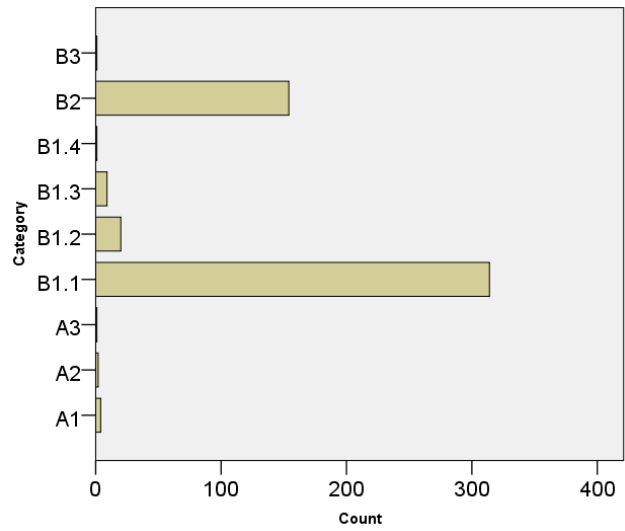

Figure 3. License Category.

It is seen that the graph in Figure 4 shows that nearly half of the applicants are graduated from civil aviation school or aviation and space science faculty. Only $20 \%$ of the applicants are graduates of authorized schools.

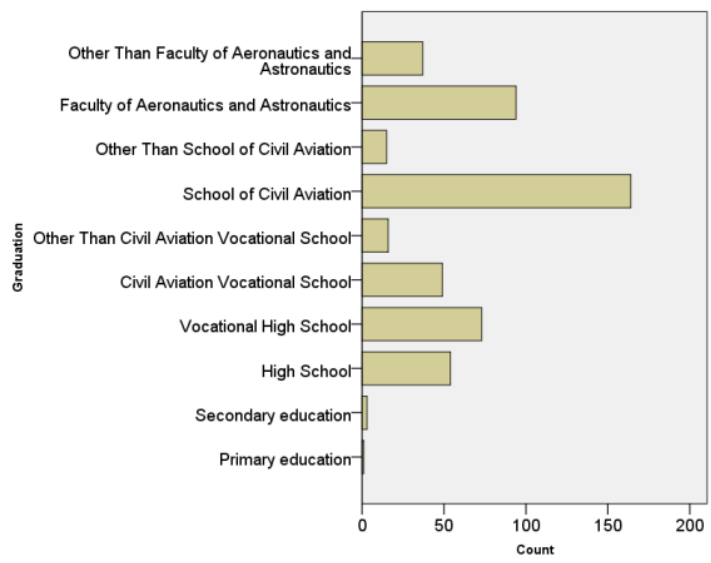

Figure 4. Graduation.

Figure 5 reveals that about $37 \%$ of those who enter the exams are students, and most of the candidates get a license after they start working. In general, it appears that the vast majority of candidates have started to take exams after they have started working. 


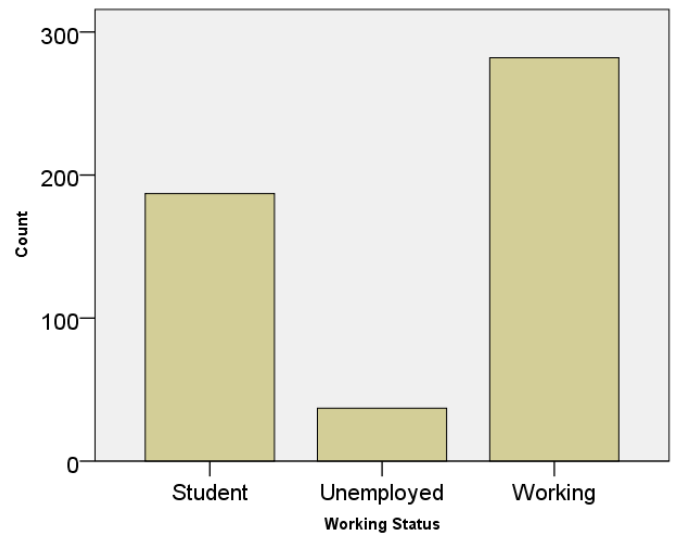

Figure 5. Working Status.

Candidates are gathered in 2 groups in the form of employees who are in the application of new license in terms of work. Most of the candidates are at the initial application stage (Figure 6).

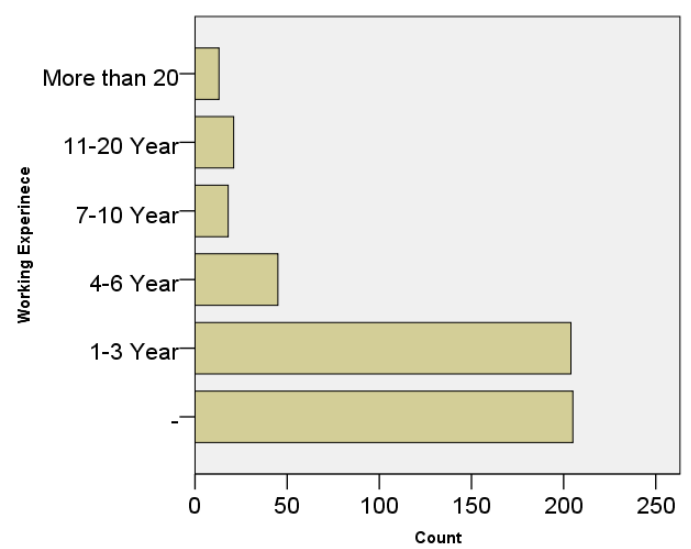

Figure 6. Working Experince.

Figure 7 shows that the majority of candidates entering the exams are candidates for first time license. A small proportion of them are seen entering the category transition or restriction removal exams. The old instruction (SHDT35) of the restriction removal exams is made up of licensed technician candidates who are taking the restriction removal exemption for the existing technicians who are licensed to pass the new instruction (SHY66). In general, it is determined that candidates with license category B2 enter the exams to take the B1.1 category license.

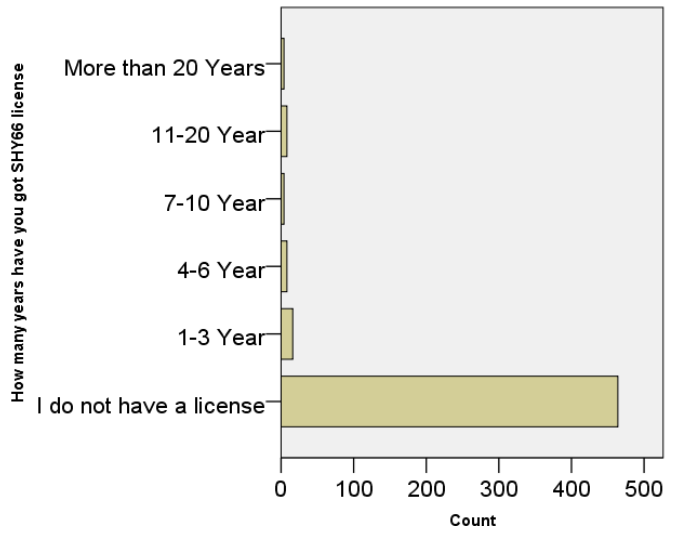

Figure 7. How Many Years Have You Got SHY66 License.

Figure 8 shows the number of candidates entering exams. The number of admission to inversely proportional examinations is decreasing.

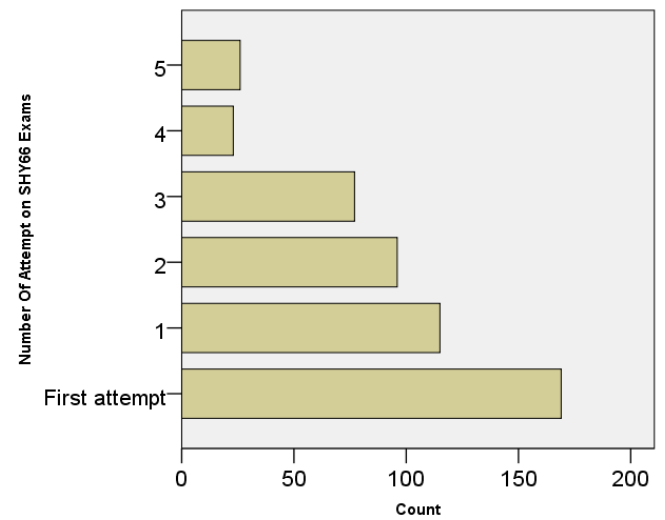

Figure 8. Number of Attempt SHY66 Exams.

Figure 9 shows that the vast majority of candidates entering the exams are candidates who want to get a license for the first time. Majority of the technicians working in SHDT-36 to SHY66 were restricted by SHGM. Over time, the candidates could be interpreted as the number being reduced because they removed these limitations.

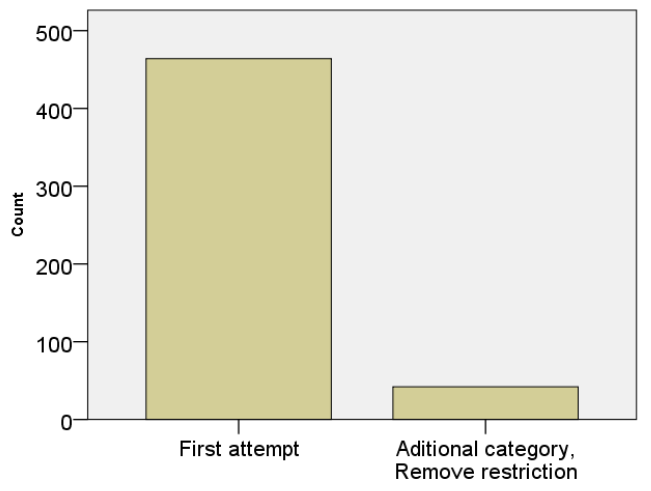

Figure 9. Type of License Attempt. 


\section{Perception of Candidates' SHY66 Module Exam}

The perception scale was developed by 506 people through the SHY66 module reference system.

Tabke 1.Case Processing Summary.

\begin{tabular}{|l|l|l|l|}
\hline & & $\mathrm{N}$ & $\%$ \\
\hline Cases & Valid & 506 & 100,0 \\
\hline & Excluded (a) & 0 &, 0 \\
\hline & Total & 506 & 100,0 \\
\hline
\end{tabular}

Listwise deletion based on all variables in the procedure.

The reliability value of Cronbach's alpha for this study is $\operatorname{good}($ alpha $=0,785)$

Table 2. Reliability Statistics.

\begin{tabular}{|l|l|}
\hline Cronbach's Alpha & N of Items \\
\hline, 785 & 11 \\
\hline
\end{tabular}

Figure 10 also shows that the majority of candidates are in the opinion that the SHY66 exams contribute to the development of technician candidates in a certain way. Candidates can also be interpreted as contributors to the study of candidates, to the research of the candidates, to the improvement of the level of knowledge, and also to the learning of new knowledge in the examination and also of the questions that the candidates answered incorrectly after the failed examinations.

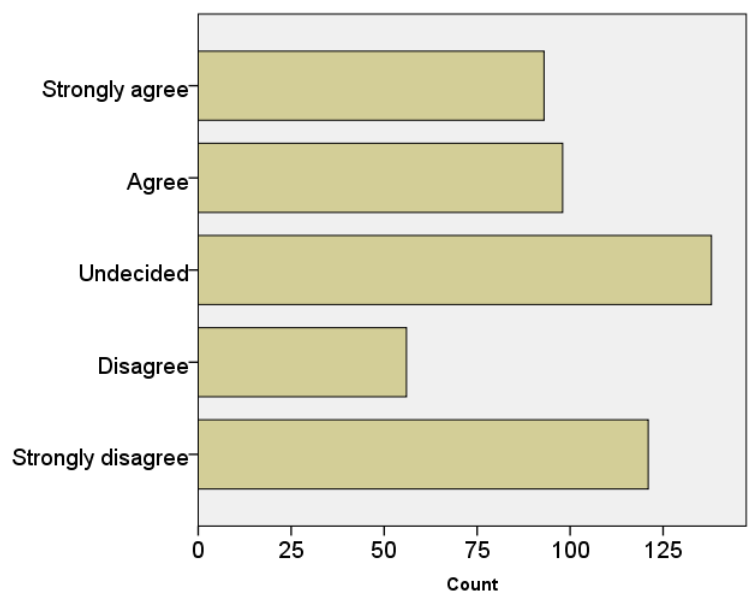

Figure 10. SHY66 Exams Help the Technician Candidate Self-İmprove.

Figure 11 can be interpreted graphically as candidates' examination questions covering the general aviation upto-date developments. The content prepared by the questions is published by the civil aviation authority according to the regulations published by the European civil aviation authority. According to technological developments, legislation is constantly updated and examination questions have to be prepared according to the contents in the current legislation.

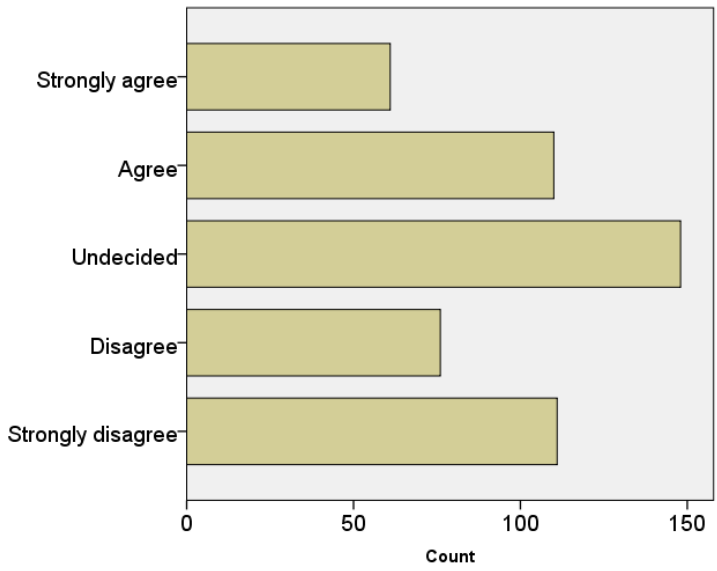

Figure 11. SHY66 Exams are an Updated Exam which Covering Developments in Aviation's.

Figure 12 can be interpreted as the SHY66 exam generally contributing to the development of critical thinking by technician candidates.

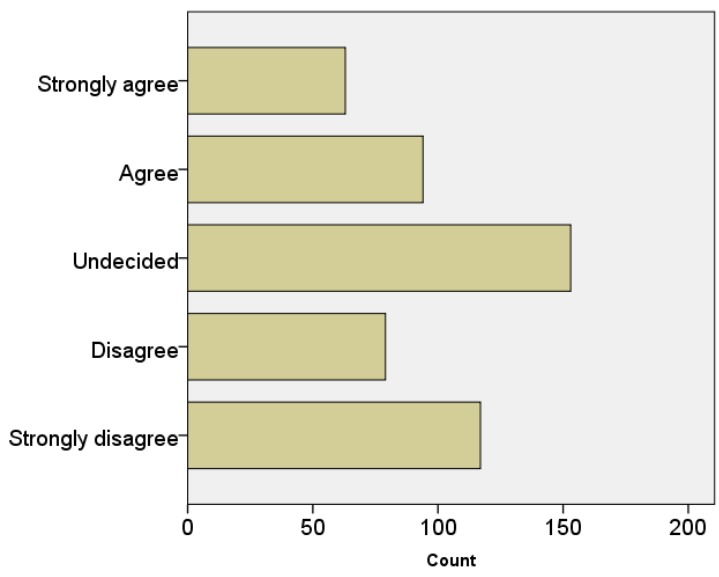

Figure 12. SHY66 Exams Support to Critical Thinking of Technician Candidates.

In Figure 13, a clear interpretation can be made that the majority of candidates are in the same opinion that SHY66 exams expect high performance from technician candidates.

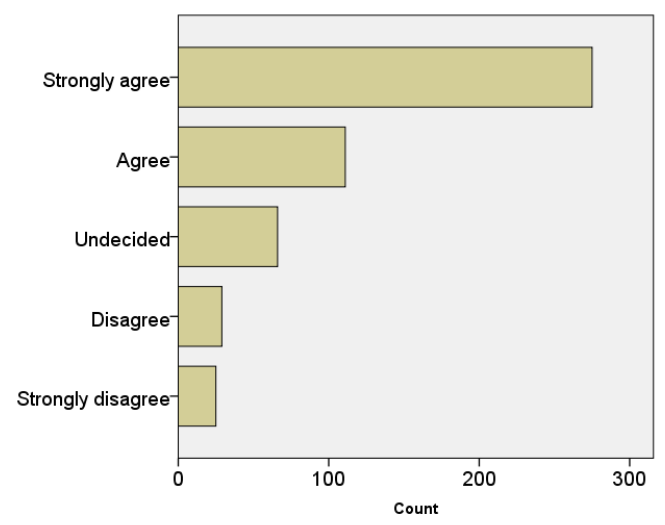

Figure 13. High Performance is Expected from Technician Candidates on the SHY66 Exams. 
Most of the applicants think SHY 66 exams prepare technician candidates for the exam, not for the profession (Figure 14).

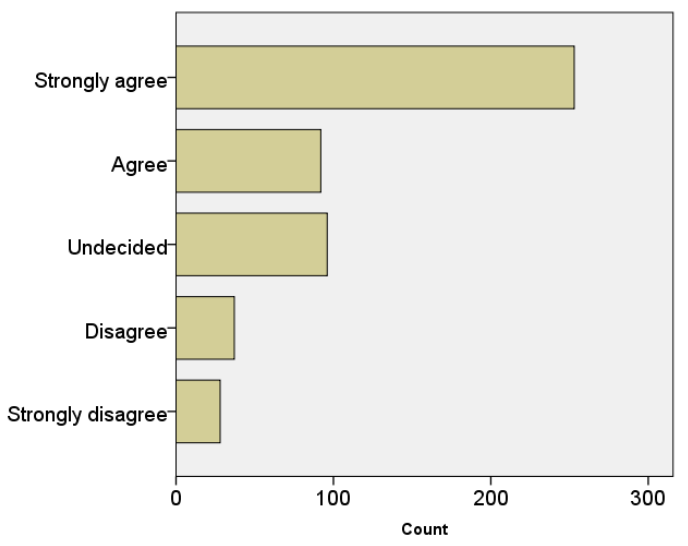

Figure 14. SHY66 Exams Prepare the Technician Candidates for not the Profession, but the Exams

Figure 15 it can be interpreted that the SHY66 exam disrupt the technician candidates' mental health.

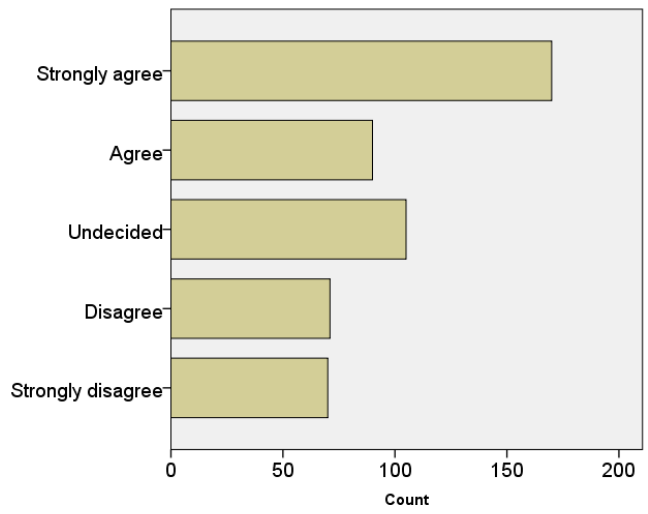

Figure 15. SHY66 Exams Disrupt the Technician Candidates' Mental Health.

Candidates think SHY 66 exams do not provide the opportunity to observe the professional background of technician candidates (Figure 16).

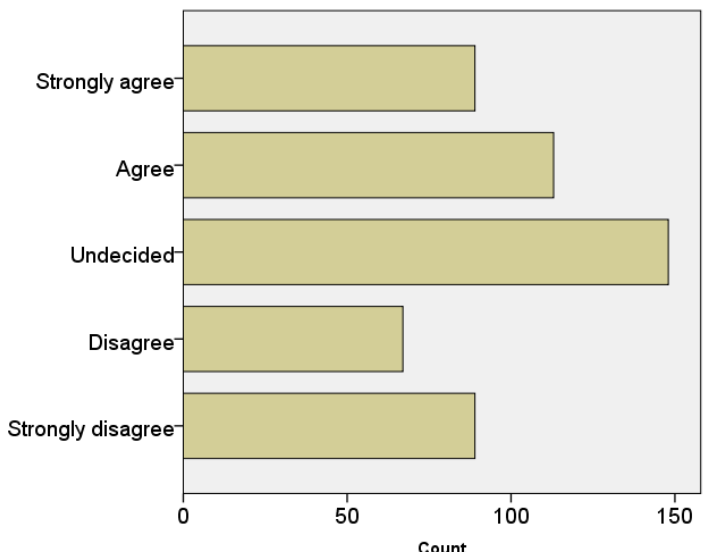

Figure 16. SHY66 Exams Provide the Opportunity for Technician Candidates to Observe Their Professional Background.
The SHY66 exams can be generally considered to be an opportunity for prospective technician candidates to assess their professional background.

\section{Conclusion}

A good assessment of the exam can be interpreted in two ways. If the majority of the candidates fail, the examining institution can be interpreted as having a very difficult and academic examination or that the candidates are not qualified enough to succeed in the examinations they have taken. If exam questions are constantly updated, candidates will be able to memorize and succeed in exams.

The fact that the average success rate in the tests is around $30 \%$ is due to the fact that the vast majority of candidates entering the examination are entering the exams for graduates from unauthorized institutions.

$37 \%$ of those who enter the exams are students, and most of the candidates get a license after they start working. It is important how much of the employees or unemployed here graduate from the competent aviation schools.

A clear interpretation can be made that the majority of candidates are in the same opinion that SHY66 exams expect high performance from technician candidates. This can be interpreted as the fact that the candidates are extremely difficult to test, and that they desire more from the technician candidates. It can be thought that the examinations can make a good measurement and evaluation in terms of the nature and results of the work being done and the candidates interpreted in this way because of the existing instructions and contents.

SHY66 exam is a general opinion that the technician candidates break their mental health. This can be interpreted as the difficulty of the source of the question, which is due to the fact that the topics and content are too numerous and very different, and that the majority of the candidates enter the exams without receiving basic education from an authorized training institution.

The SHY66 exams can be generally considered to be an opportunity for prospective technician candidates to assess their professional background. In aeronautics, aerosol and training are very important. Candidates can forget the information they have received in training in time if the information in the trainings given within a certain period of time after training is not used very frequently. All candidates who are engaged in aeronautics profession are required to take refresher training in certain periods. Even licensed technicians, in fact, training in certain periods to refresh or test their knowledge with such exams is important in terms of safety.

* This research was prepared scope of SHY66 exam system development's project within the Computer Research. Multiple questionnaires were apply on the participants. 


\section{References}

1. Ghobbar, A. A., Friend, C. H., The Material Requirement Planning System For Aircraft Maintenance and Inventory Control: A Note, Journal of Air Transport Management, 2014, 10(3), $217-$ 221 .

2. SHGM, Sivil Havacılık Genel Müdürlüğü, Onayıi Hava Arac Bakım Kuruluşları Talimatı (Sht-145), Sivil Havacılık Genel Müdürlüğü, 2013, Ankara.

3. Hobbs, A., Williamson, A., Skills, Rules and Knowledge in Aircraft Maintenance: Errors in Context, Ergonomics, 2002, 45(4), 290-308

4. Kraus, D., Gramopadhye, A. K., Team Training: Role of Computers in The Aircrfat Maintenance Environment, Computers \& Industrial Engineering, 1999, 36(3), 635-654.

5. Young,T.M., Aircraft Design Education at Universities: Benefits and Difficulties, Aircraft Design, 2000, 3(4), 207-264.

6. Gülgü, A.F., Uçak Bakım Teknisyeni Nasıl Olunur?, http://www.ucakteknisyeni.com/ucak-bakim-teknisyeni-nasilolunur.html, 2012, (accessed 08.07.2017).

7. SHGM, Sivil Havacılık Genel Müdürlügü̈, Hava Aracı Bakım Personeli Lisans Yönetmeliği (Shy 66 - 01), Ulaştırma Bakanlığı, 2007, Ankara

8. Atak, A., Kingma, S., Safety Culture in An Aircraft Maintenance Organisation: A View From The Inside, Safety Science, 2011, 49(2), 268-278.

9. Lan, T.H., Coalition of Vocational and Regular Aviation Maintenance Technician Education, Proc. International Conference on Engineering Education, Manchester, UK, 2002.

10. Kasava, N.K., Yusof, N.M., Khademi, A., Saman, M.Z.M. Sustainable Domain Value Stream Mapping (SdVSM) Framework Application in Aircraft Maintenance: A Case Study, Procedia CIRP, 2015, 26, 418-423.

11. Stadnicka, D., Ratnayake,R.M.C., Enhancing Aircraft Maintenance Services: A VSM Based Case Study, Procedia Engineering, 2017, 182, 665-672.

12. Saraçyakupoğlu, T., Türkiye'de Havacılık Endüstrisinde Bakım Teknisyeni Yetiştirme Patikası, Mühendis ve Makina, 2016, 57(678), 60-64.

13. SHGM, Sivil Havacılık Genel Müdürlüğü, Yetkili Bakım Kuruluşları, http://web.shgm.gov.tr/tr/havacilik-isletmeleri/2064yetkili-bakim-kuruluslari, 2015 (accessed 08.07.2017).

14. Sahay, A., Aircraft Maintenance Paradigm, Leveraging Information Technology for Optimal Aircraft Maintenance, Repair anad Overhaul, Vol. 3, , Chandogya Upanishad, Upanisads, Oxford University Press., U.S.A., 2012, pp 221-230.

15. SHGM, Sivil Havacılık Genel Müdürlüğü, SHY-147 Kapsamında Tanınan Okul Statüsü, Sivil Havacılık Genel Müdürlüğü, 2014 Ankara

16. SHGM, Sivil Havacılık Genel Müdürlüğü, Hava Aracı Bakım Eğitimi Kuruluşları Talimatı (Sht-147), Sivil Havacılık Genel Müdürlüğü, 2007, Ankara.

17. SHGM, Sivil Havacilık Genel Müdürlüğü (n.d.), Hava Arac Bakım Personeli Lisans Yönetmeliği (SHY 66-01) Dönüșüm Talimatı, http://web.shgm.gov.tr/tr/genel-duyurular/1072-havaaraci-bakim-personeli-lisans-yonetmeligi-shy-66-01donusum- talimati-yayimlanarak-yururluge-girmistir, $2017 \quad$ (accessed 08.07.2017).

18. Akalın, Ş., Kamu Personeli Seçme Sınavı Genel Yetenek Testinin Madde Yanlılığı açısından İncelenmesi, Doktora Tezi, Ankara Üniversitesi, Eğitim Bilimleri Enstitüsü, 2014, Ankara.

19. Önal, B., Sınıf Öğretmeni Adaylarının Kamu Personeli Seçme Sınavındaki Başarı Düzeylerinin Bazı Değişkenler Açısından Incelenmesi, Yükseklisans Tezi, Uşak Universitesi, Sosyal Bilimler Enstitüsü, 2011, Uşak.

20. Joosung J. Lee, J.J., Yoon, H., A Comparative Study of Technological Learning and Organizational Capability Development in Complex Products Systems: Distinctive Paths of Three Latecomers in Military Aircraft Industry, 2015, 44(7), 12961313 